\title{
Computer-Assisted Language Learning and the Improvement of Communicative Competence
}

\author{
Qibin He \\ School of Foreign Languages and Culture, Beijing Wuzi University, Beijing, 101149, China
}

\begin{abstract}
Communicative competence which covers all aspects of language use has always been the goals to reach both for the language teachers and undergraduates in their English language teaching and learning. As English is the foreign language with no or little language environment for students to pick up the language outside the educational institutions, information technology and computer network which have been widely used in higher education provide vivid English with the virtual environment of the video and audio resources. The practice of using information technology to teach English has been widely adopted in the English language classroom. The paper aims at discussing on the development of students' communicative competence supported by the computer-assisted language learning (CALL).
\end{abstract}

Keywords-CALL; communicative competence; information technology.

\section{INTRODUCTION}

Communicative competence which covers all aspects of language use has always been the goals for the learners to reach in the curriculum of higher education. As English is a foreign language that can only be learnt in the educational institutions in China, most of the students have no or little opportunities to pick up the English language when they go out of the English classrooms. With the introduction of computer and information technology to the foreign language education, colleges and universities of higher education in China have set up multimedia and digital language laboratories with the support of government finance. The modernized digital language laboratories enable the college students to immerse in the virtual language environment which is built by the computer and network with the rich resources of native English. By viewing, listening and watching the online learning resources of English language, students may immerse in the English language environment with the native speakers' English and obtain enormous input that enables learners to be ready to speak fluently. However, every coin has two sides. On the one hand, the new technology provides the foreign language learners with the authentic English from speakers of English speaking countries, and the students may benefit from the real-life English that is good for their language use and future-career development; on the other hand, the new mode of teaching which is quite different from the traditional classrooms teaching challenges both the teachers' teaching philosophy and students' learning styles. Confronted with the issues initiated by the fast development of information technology, the paper will focus on the ways to improve learners' communicative competence by using computer and network-based language teaching and learning.

\section{THEORETICAL FRAMEWORK}

\section{A. Definitions of communicative language teaching}

Communicative language teaching (CLT) or communicative approach which is originated form late 1960 s and prominent in late 1970s and early 1980s is an approach to language teaching. Richards suggests that communicative language teaching can be understood as a set of principles about the goals of language teaching, how learners learn a language, the kinds of classroom activities that best facilitate learning, and the roles of teachers and learners in the classroom” (Richards, 2010, p. 21).

"Howatt distinguishes Communicative Language Teaching between a strong version and a weak version. The weak version stresses the importance of providing learners with opportunities to use their English for communicative purposes; the strong version of communicative teaching on the other hand advances the claim that language is acquired through communication. (Howatt, 1984.p. 279; from Richards \& Rodgers, 1991, p. 66).

\section{B. Theoretical basis of communicative competence}

Communicative competence is a term that underlies the communicative approach or communicative language teaching (CLT) to second or foreign language teaching. It is first coined by Dell Hymes in 1966 in opposition to Chomsky's linguistic competence, and it is the ultimate goal to reach in the Communicative Language Teaching. Canale and Swain (1980) defined communicative competence in second language education in terms of three components

1) grammatical competence: words and rules

2) sociolinguistic competence: appropriateness

3) strategic competence: appropriate use of communication strategies

It is important to gain each of three competences in the development of successful communication. Canale and Swain argue that "There is no strong theoretical or empirical motivation for the view that grammatical competence is any more or less crucial to successful communication than is sociolinguistic competence or strategic competence. The primary goal of a communicative approach must be to facilitate the integration of these types of knowledge for the learner, an outcome that is not likely to result from 
overemphasis on one form of competence over the others throughout a second language program (Wikipedia). Therefore communicative language teaching curriculum should include these three elements of competence in every teaching process.

Richards (2010) suggests the following aspects of language knowledge that the communicative competence includes:

1) Knowing how to use language for a range of different purposes and functions

2) Knowing how to vary our use of language according to the setting and the participants (e.g. knowing when to use formal and informal speech or when to use language appropriately for written as opposed to spoken communication)

3) Knowing how to produce and understand different types of texts (e.g. narrative, reports, interviews, conversations)

4) Knowing how to maintain communication despite having limitations in one's language knowledge(e.g. through using different kinds of communication strategies)

(Richards, 2010, p. 22).

In the domain of second language acquisition, communicative language teaching has always been deemed as a successful method in developing learners' communicative abilities. However, critiques of communicative language teaching was offered by the writer for paying insufficient attention to the context in which teaching and learning take place (Wikipedia). While language learning context is one of the most important elements that result in successful language learning in the foreign language settings, computers and network technologies may create an enormous virtual environment for the learners to raise their competence in language communication through learning by doing with the computers and modern instructional technology.

\section{Theoretical framework of computer-assisted language learning}

With the emergence of personal computers and the fast development of information technology since 1990s, "the wide spread use of software, local area networks (LANs) and internet has created enormous opportunities for learners to enhance their communicative abilities"(Hanson-Smith, 2001, p. 107) in the foreign language learning.

The advances in information technology have necessitated new approaches and methodologies in the area of foreign language learning and thoroughly teaching. With the fast development and widely application of multimedia personal computer, the language teaching methodologies of communicative approaches, content-based learning and task-based learning are all enhanced by the use of the computer. Computer-assisted language learning (CALL) has branched out in many ways in communicative pedagogy (Hanson-Smith, 2001, p. 107).

Another program of Computer-assisted language teaching is the technology-enhanced language learning which was greatly boosted by the theory of constructivism when Sydney Papert(1993)- the creator of computer language Logo- and others applied the principles of Dewey (1938) and Piaget ( 1950$)$ to the use of computers ( Hanson-Smith, 2001, p. 107).

Constructivism is a theory about knowledge and learning (Fosnot, 1996). The constructivist view of knowledge is that knowledge is constructed and learning is the process of construction. There exists a complementary relationship between constructivist practice and technology. Like constructivism, technology has transformed the teaching-learning process. It has been used in many classrooms to foster meaningful learning experiences (Jonassen, Peck, \& Wilson, 1999). Jonassen and Yueh (1998) argue that "technologies should not support learning by attempting to instruct the learners, but rather should be used as knowledge construction tools that students learn with, not from"

The Internet and the virtual learning environments have diversified the opportunities for teachers and learners to employ the computer and internet as tools to construct knowledge. Jonassen, \&Yueh (1998) maintain that "Constructivist approaches to learning strive to create environments where learners actively participate in the environment in ways that are intended to help them construct their own knowledge, rather than having the teacher interpret the world and insure that students understand the world as they have told them"

Computers can most effectively support meaningful learning and knowledge construction in higher education,... they should be used in all subject domains as tools for engaging learners in reflective, critical thinking about the ideas they are studying (Jonassen, \&Yueh, 1998, p.31).

\section{THE APPLICATION OF COMPUTER-ASSISTED LANGUAGE LEARNING}

\section{A. Requirements of new national curriculum}

"College English Curriculum Requirements (CECR)" formal version is the national curriculum released by the Ministry of Education in 2007.

According to the CECR, the character and objective of college English teaching is to develop students' ability to use English in a well-rounded way, especially in listening and speaking, so that in their future studies and careers as well as social interactions they will be able to communicate effectively, and at the same time enhance their ability to study independently and improve their general cultural awareness so as to meet the needs of China's social development and international exchanges.

The teaching model in the CECR has been changed from the existing unitary teacher-centered pattern of language teaching to computer-and classroom-based teaching models. The new model should be built on modern information technology, particularly network technology. Colleges and universities should explore and establish a Web-based listening and speaking teaching model that suits their own needs in line with their own conditions and students' English proficiency, and deliver listening and speaking courses via the intranet or campus network.. 
Instructions of "Computer- and Classroom-Based College English Teaching Model” have been designed in the CECR. Teaching activities such as listening, speaking, reading, writing and translation can be conducted via either the computer and Web-based environment or classroom teaching. Specifically, listening ability is trained mainly in a computer- and Web-based environment, supplemented by classroom teaching; writing and translation are trained mainly in the classroom, supplemented by a computer- and Web-based environment; speaking and reading, on the other hand, are trained by both means of classroom teaching and Computer and Web-based environment. In the process of teaching, teachers' roles are served as organizers of teaching activities, and teaching administration is implemented by the administrative office of teaching affairs, teachers, and teaching management software. 2007

Higher Educational Department of Ministry of Education,

\section{B. The teaching practices of CALL in Beijing Wuzi University}

Underpinning the guidelines of CECR, College English in Beijing Wuzi University has been designed as three courses for the purpose of developing students' communicative competence. As students are generally weak in listening and speaking abilities, College English of non-English majors are set up as i) Reading and Writing Course that mainly focuses on reading, writing and translating skill; ii) Listening and Speaking Course that focuses on speaking skill; iii) English Practice Course that focuses on listening skill. The teaching activities are conducted either in the place of classrooms or Computer and Web-based environment of language laboratories according to the instructions in the CECR. The three courses aim at specific skill in teaching, and at the same time they are interrelated in developing the five skills in the real teaching practice.

As the ultimate goal of College English is to develop students' communicative competence, especially in listening and speaking, therefore students' listening ability are taught and practiced in the English Practice Course which is conducted in the Computer and Web-based environment of language laboratories. The language laboratories have been equipped with advanced teaching and learning software that enables the teachers to make full use of the modern instruction technology to give the lectures with the teacher's computer, and students may practice their listening and speaking skills and do their self -access learning tasks with their own step after teacher's lectures.

College English Practice course is the general compulsory course which offers four credits for four semesters to the freshmen and sophomore students. The course is given two periods of 100 minutes in every other week in each semester. The main task of English Practice Course is to take the advantage of online learning environment to develop students' listening ability, raise students' autonomous learning ability, and at the same time give students enough input by listening and viewing so that students may have the opportunities to raise their communicative competence in the authentic foreign language environment

The teaching materials of English Practice Course are New Horizon College English (NHCE) Viewing, Listening and Speaking and its supporting online materials in the network-based NHCE learning management system. The online learning management system provides both student learning platform and teacher's management platform. Teachers can use each module in teacher's management platform to set tasks for students to do after-class autonomous online learning, test students with online quiz bank and evaluate students' learning performance with the evaluation norms in the NHCE learning management system. By making full use of each managing module in the NHCE language learning management, students' performance can be learnt by checking up students' record of online learning process, achievements in the testing reports, percentage of correctness in doing exercises and the time students afforded in the online learning.

\section{Reflections on the teaching of CALL}

Computer-assisted language learning is "the search for and study of applications of the computer in language teaching and learning”(Levy, 1997: p.1). It is an approach that can best improve learners' communicative competence with the virtual environment supported by the computer and information technology. The practice of English Practice Course in Beijing Wuzi University shows that students who are weak in English language knowledge and self-regulation in autonomous learning may make progress by taking the course.

For one thing, the course may effectively enhance the teaching quality in the in-class lectures with paying special attention to the differences of each student's English level. Because students may have the opportunities to acquire the English knowledge by practicing their comprehensive skills, especially the listening skill in their own pace and steps according to the difficulty degrees the learning material to each student. Take the listening skill for example, after teachers teach the listening skills in the class, students who take the course in the language laboratory might not have to do the listening as students do in the traditional classroom. No matter the individual student understand the listening material or not, all the students in the tradition classroom have to listen to the recordings with the teacher's click on the computer to decide the times the listening material is played.

For another thing, making full use of the online NHCE learning management system in the English Practice Course can build up students' confidence and stimulate students' motivation to learn the foreign language by keeping practicing. Because the course evaluate students' performance with formative assessment and the teacher can guide the students learning and monitor students' learning process all the way through the record of how students do their online learning by checking up the software of the NHCE learning management system. 


\section{CONCLUSION}

Piaget (1977) asserts that learning occurs by an active construction of meaning, rather than by passive percipience. Computer-assisted language learning which is best promoted by the constructivism can effectively improve students' communicative competence by providing the students with the authentic language learning environment, and efficiently perform learner-centered and teacher-guided features of communicative language teaching and leaning with the advanced language learning and teaching software in the language laboratories. English Practice Course that is set up for the goal of improving on students' communicative abilities may motivate students to raise their communicative competence by paying special attention to students' learning performance rather than their achievements in specific testing scores.

\section{REFERENCES}

[1] Canale, M.; Swain, M. (1980). "Theoretical bases of communicative approaches to second language teaching and testing". Applied Linguistics (1): 1-47. Retrieved September 29, 2013.

[2] Carter, R. \& Nunan, D. (2001). Computer-Assisted Language Learning. In Carter, R \& Nunan, D. The Cambridge Guide Teaching English to Speakers of Other Languages. Cambridge: Cambridge University Press.

[3] Cook, G. (2012). Applied Linguistics, Shanghai Foreign Language
Education Press.

[4] Fosnot, C. T. (1996). Constructivism: Theory, perspectives, and practice. New York: Teachers College, Columbia University.

[5] Higher Educational Department of Ministry of Education, (2007), College English Curriculum Requirements Beijing: Foreign Language Teaching and research Press.

[6] Jonassen, D.H. Carr, C \&Yueh, HP (1998). Computers as Mindtools for Engaging Learners in Critical Thinking TechTrends, v43 n2 p24-32 Mar

[7] [7] Jonassen, D. H., Peck, K. L., and Wilson, B. G. (1999). Learning with technology: A constructivist perspective. New York: Prentice Hall.

[8] Levy M. (1997) CALL: context and conceptualisation, Oxford: Oxford University Press.

[9] Littlewood, W. 1981. Communicative Language Teaching. Cambridge: Cambridge University Press.

[10] Piaget, J. (1977). The development of thought: Equilibration of cognitive structures. (A. Rosin, Trans). New York: The Viking Press.

[11] Richards, J.C. \& Rodgers, T.S. (1991). Approaches and Methods in Language Teaching- A description and analysis. Cambridge: Cambridge University Press.

[12] Richards, J.C. (2010). Selected Works of Jack C. Richards on Applied Linguistics. Beijing: Foreign Language Teaching and Research Press.

[13] Wikipedia, http://en.wikipedia.org/wiki/Communicative_language_teaching

[14] Wikipedia,http://en.wikipedia.org/wiki/Computer-assisted_language_ learning. 